\title{
Epiphyte biomass and nutrient capital of a moist subtropical forest in north-eastern Taiwan
}

\author{
CHIA-CHUN HSU*, FU-WEN HORNG $\dagger^{1}$ and CHEN-MENG KUO* \\ * Department of Botany, National Taiwan University, Taipei, Taiwan \\ + Taiwan Forest Research Institute, 53 Nan-Hai Road, Taipei 100, Taiwan \\ (Accepted 3rd September 2001)
}

\begin{abstract}
A plot of $1200 \mathrm{~m}^{2}$ was selected to represent the average epiphyte abundance of a moist subtropical broadleaved forest at Fushan in north-eastern Taiwan. In this plot, all epiphytes of 18 sample trees with $\mathrm{dbh}>5 \mathrm{~cm}$ were removed and weighed to estimate their biomass and nutrient content. We found that the biomass of epiphytes and their associated detrital matter in this plot was $3360 \mathrm{~kg} \mathrm{ha}{ }^{-1}$. The nutrient capital of the epiphytes $\left(\mathrm{kg} \mathrm{ha}^{-1}\right)$ was: $\mathrm{N}=42.4, \mathrm{P}=$ $1.9, \mathrm{Mg}=5.5, \mathrm{Na}=1.3, \mathrm{Ca}=14.5$ and $\mathrm{K}=28.9$. Although the epiphytic biomass constituted less than $2 \%$ of the total above-ground biomass of the forest, the epiphytes comprised about $21-43 \%$ of the total foliage nutrient capital of the ecosystem. Because nutrients contained in epiphytes and tree foliage are more readily available to other organisms than those in woody components, epiphytes may play a greater role in ecosystem nutrient cycling than their relatively small biomass would suggest.
\end{abstract}

KEY WORDS: Bryophytes, Fushan, hardwood forest, pteridophytes

\section{INTRODUGTION}

The effect of epiphytes on ecosystem-level functions has been increasingly studied for the past two decades. Many of the past studies focused on the role of epiphytes in biomass accumulation and nutrient cycling in ecosystems; however, most of the data on the role of epiphytes in ecosystems came from moist temperate and tropical regions (Denison 1973, Edwards \& Grubb 1977, Golley et al. 1971, Hofstede et al. 1993, Nadkarni 1984a, b; Pike 1978, Pócs 1980). Relatively few studies provided detailed information on phorophyte surface area, epiphytic biomass and nutrient capital of the forest ecosystem.

Because of their efficiency in intercepting and retaining nutrients from the atmosphere, epiphytes can be important participants in the nutrient cycling in

${ }^{1}$ Corresponding author. Email: horng@serv.tfri.gov.tw 
an ecosystem (Benzing 1990, Pócs 1976). Although epiphytes comprise a very small proportion of the total forest biomass, their contribution to productivity and nutrient capacity can be similar to or even greater than that of the phorophyte foliage in the ecosystem (Hofstede et al. 1993, Nadkarni 1984a, b).

The Fushan Experimental Forest is located in a subtropical region in northeastern Taiwan. Because of its warm and continuously humid environment, epiphytes make up a conspicuous portion of this moist broadleaved evergreen forest. There are more than 100 species of epiphytes in this forest, which combined with its frequently cloudy weather pattern, shows a similar physiognomy to that of tropical cloud forests. Consequently, we hypothesized that epiphytes may contribute to a relatively similar pattern of biomass and nutrient accumulation as their counterparts in tropical moist cloud forests.

The purpose of the study was to estimate the amount of biomass and nutrient capital in the epiphytes and their associated detrital matter in this moist subtropical broadleaved evergreen forest. In addition, their relative contribution to the total above-ground ecosystem was calculated. The results were compared with epiphytic loads in tropical, subtropical and temperate forest ecosystems.

STUDY SITE

The study site was located in the Fushan Experimental Forest $\left(24^{\circ} 46^{\prime} \mathrm{N}\right.$, $121^{\circ} 43^{\prime} \mathrm{E}$ ), approximately $35 \mathrm{~km}$ from Taipei City in north-eastern Taiwan. The forest has been a long-term ecological research site of the National Science Council since 1990 (Figure 1).

The total area of the forest is $1098 \mathrm{ha}$, and ranges from 400 to $1400 \mathrm{~m}$ elevation. The climate is warm and humid with heavy rain and fog in the winter as a result of north-east monsoons. It is frequently struck by strong typhoons in summer and early autumn. During 1993-1997, the average annual temperature was $18.2^{\circ} \mathrm{C}$, and the average annual precipitation was $3600 \mathrm{~mm}$ with 221 rainy days. There is no dry season. The average annual relative humidity was $96 \%$.

A plot of $1200 \mathrm{~m}^{2}(20 \mathrm{~m} \times 60 \mathrm{~m})$ was set out on an acidic soil with a slightly inclining slope at $750 \mathrm{~m}$ elevation. The forest canopy here is about $8-15 \mathrm{~m}$ high and is a mixed broadleaved forest dominated by Lauraceae and Fagaceae. Common canopy trees include Castanopsis carlesii (Hemsl.) Hayata var. sessilis Nakai (Fagaceae), Machilus thunbergii Sieb. \& Zucc., Machilus zuihoensis Hayata (Lauraceae), Engelhardtia roxburghiana Wall. (Juglandaceae), Meliosma squamulata Hance (Sabiaceae), Diospyros morrisiana Hance (Ebenaceae), Schefflera octophylla (Lour.) Harms (Araliaceae) and Pyrenaria shinkoensis (Hayata) Keng (Theaceae). The understorey vegetation consists mainly of Blastus cochinchinensis Lour. (Melastomataceae), Alsophila podophylla Hook. (Cyatheaceae), Diplazium dilatatum Blume (Athyriaceae), Lasianthus spp. (Rubiaceae), Calanthe formosana 


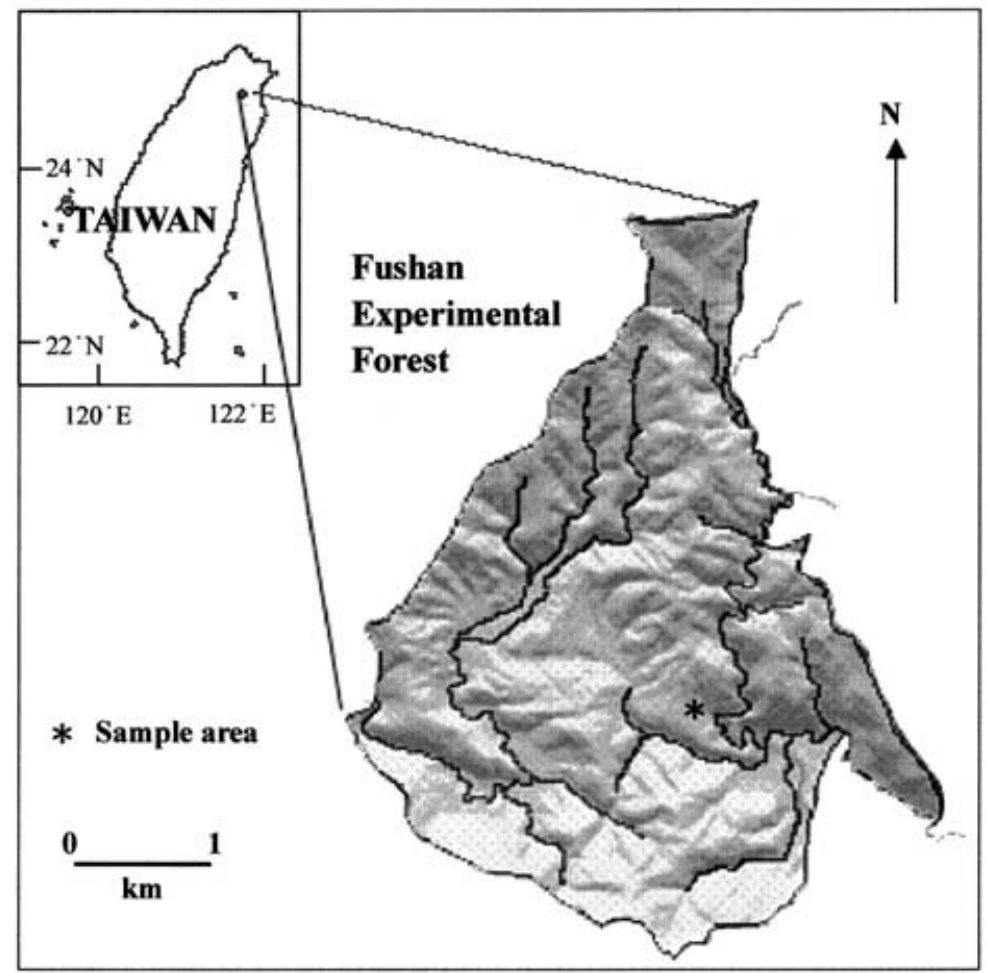

Figure 1. Location of study area (black lines inside boundary are rivers).

Rolfe (Orchidaceae), and Cephalantheropsis gracilis (Lindl.) S. Y. Hu (Orchidaceae).

\section{METHODS}

Epiphytes located on small trees $(\mathrm{dbh}<5 \mathrm{~cm})$ were very small and infrequent, so were disregarded. All 147 trees with $\mathrm{dbh}>5 \mathrm{~cm}$ in the plot were grouped into five classes by $10-\mathrm{cm}$ increments in dbh. In each class, 4-6 sample trees were selected randomly, with 21 trees in total.

Each phorophyte was subdivided into five sections to indicate epiphyte location on the tree: trunk base up to $3 \mathrm{~m}$ above the ground, the trunk, the main branching point, the lower canopy (the primary branch), and the upper canopy (modified from Johansson 1974). For some old trees with the first main branching point lower than $3 \mathrm{~m}$ above the ground, all large forks were considered the main branching point (Figure 2). In addition, the main branching point was defined as the portion within $50 \mathrm{~cm}$ of the inversion point.

A nail ladder and mountain-climbing equipment were used to remove the entire epiphytic mass from each tree. Epiphytes on twig tips were sampled by cutting off one complete branch and extrapolating to estimate the amounts for 


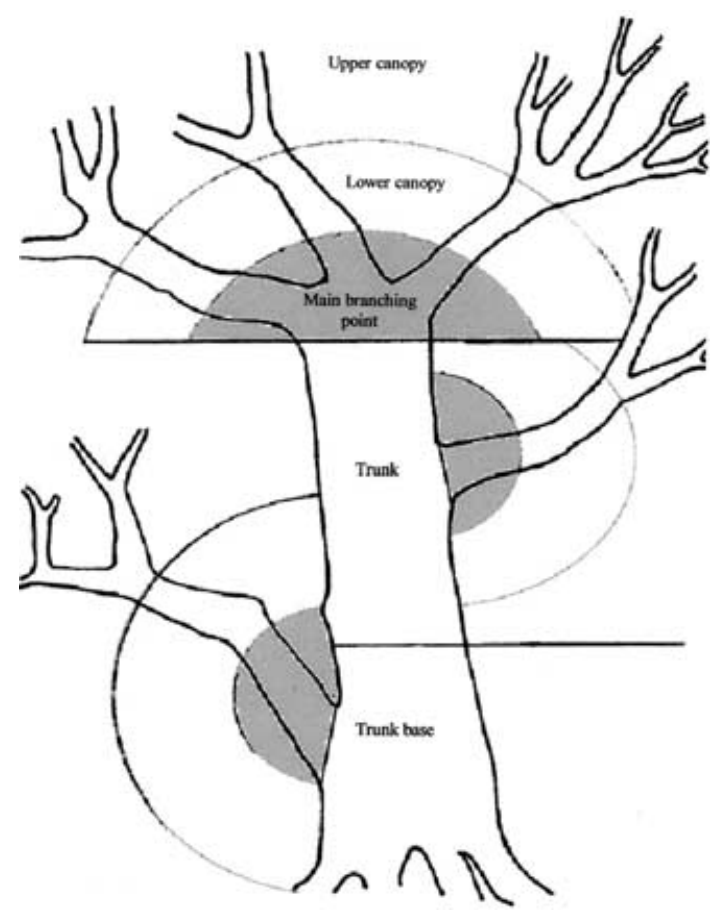

Figure 2. Epiphyte location for old trees having the first main branching points below $3 \mathrm{~m}$ from the ground. By considering the characteristics of forks and organic detritus, all large forks were assigned to the main branching point.

all branches of a phorophyte. Because only a small amount of moss was present on twig tips, such an estimation was considered reasonable.

The surface area of the phorophyte was measured by determining the length and diameters both ends of all trunk and branch segments. These segments were assumed to be tapered cylinders, and their surface area calculated accordingly.

Dry weight to substrate surface area ratios for bryophytes were calculated from the mean value of five $200 \mathrm{~cm}^{2}(10 \mathrm{~cm} \times 20 \mathrm{~cm})$ randomly selected samples in each component of a phorophyte. This was multiplied by the total surface area of each component of the phorophyte obtaining total bryophyte biomass.

Epiphytes were separated into (1) bryophytes, (2) filmy ferns (Hymenophyllaceae), (3) bird's nest ferns, (4) all other ferns, (5) epiphytic vines, (6) hemi-epiphytic vines, (7) flowering plants and (8) accumulated detritus and suspended soil. Flowering plants were divided into roots, stems and leaves. Ferns were divided into root-stems and leaves. The bird's nest ferns were divided into leaves, trapped litter, root-stems, organic substrate and fine roots.

All epiphytic samples were weighed in the field, and taken to the laboratory for dry-weight determination. One random subsample of mixed bryophytes was selected on each tree sampled. Three random subsamples of organs of each 
species were oven-dried at $65{ }^{\circ} \mathrm{C}$ for $48 \mathrm{~h}$ and ground into a size smaller than $0.5 \mathrm{~mm}$ for nutrient determination. A sample $(20 \mathrm{~g})$ of ground material was then oven-dried at $105^{\circ} \mathrm{C}$ for biomass determination.

Subsamples were taken and digested in different ways for nutrient analysis following Page (1982).

(1) Total nitrogen. Subsamples of epiphytes and suspended soil were digested in a sulphate acid mixture with copper sulphate and selenium at $420^{\circ} \mathrm{C}$. Total nitrogen was analysed with an auto-analyser.

(2) Phosphorus, potassium, calcium, magnesium and sodium. Epiphyte samples were burnt to ash at $490{ }^{\circ} \mathrm{C}$. The ash and suspended soil were extracted with acid as described above. Elements were determined by inductive-coupled plasma (ICP).

After the biomass and nutrient content of each subcomponent were determined, they were used to estimate the total epiphytic biomass and nutrient content of each sample tree. Regression analyses were applied to obtain relationships between phorophyte dbh and their epiphytic biomass. The data of three trees were not used because they were partially dead or bordered the forest path. The regression equation then was used to estimate the total epiphytic biomass and nutrient content of the plot.

\section{RESULTS}

A total of $115 \mathrm{~kg}$ of epiphytic biomass was removed from 18 sampled phorophytes. The dbh of the phorophytes and the epiphytic biomass were highly correlated $\left(\mathrm{r}^{2}=0.87 ; \mathrm{P}<0.05\right)$ (Figure 3$)$. Based on the regression equation and the dbh of the remaining 126 trees in the sample plots, the total epiphytic biomass was estimated to be $403 \mathrm{~kg}$ in the sampled plot $\left(1200 \mathrm{~m}^{2}\right)$. The epiphytic biomass for the entire forest was estimated to be $3360 \mathrm{~kg} \mathrm{ha}^{-1}$.

The epiphytic biomass constituted less than $2 \%$ of the total above-ground biomass (including woody material), but it is equivalent to about $43 \%$ of the biomass of total foliage in the ecosystem (Table 1). Green tissues of epiphytes represented $64.2 \%$ of the total epiphytic biomass (Table 2), whereas in the phorophytes, photosynthetic tissues constituted $2.1 \%$ of the total biomass of the phorophytes.

The epiphytic biomass varied widely depending on location in the phorophyte canopy (Figure 4). Occurrence of epiphytic biomass was 16, 36, 24, 21 and 3\% on the trunk foot, trunk, main branching point, lower canopy and outer canopy respectively. On the main branching point and in the lower canopy, about 60$70 \%$ of the total epiphytic biomass consisted of bryophyte mats. Ferns, especially Pyrrosia lingua (Thunb.) Farw. (Polypodiaceae), were most abundant $(40 \%)$ in the outer canopy. Bird's nest ferns occurred in the lower levels of the phorophyte canopies, but were most abundant (25\%) on the trunk. Epiphytic vines were evenly distributed in each area of the phorophyte canopy, comprising about $10 \%$ of the epiphytic biomass. Hemi-epiphytic vines were most abundant $(30 \%)$ in the outer canopy. 


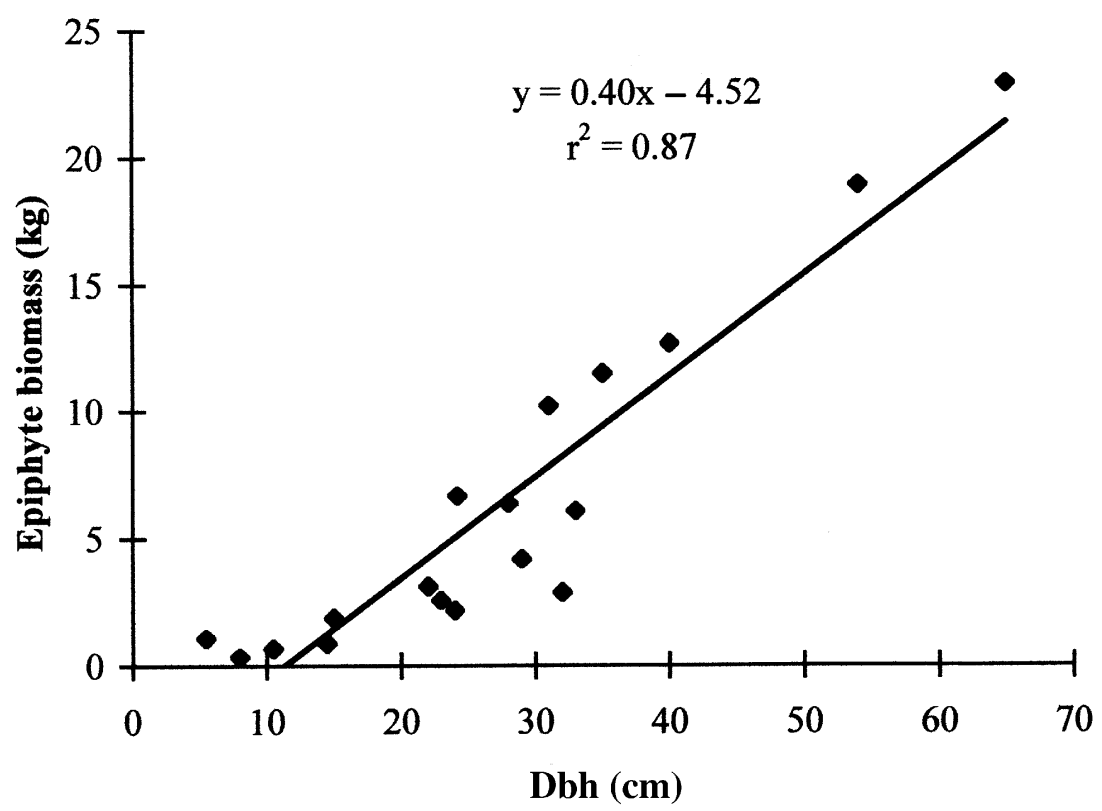

Figure 3. Relationship between total epiphyte biomass and dbh of 128 trees at Fushan in north-eastern Taiwan.

Table 1. Proportion of total biomass in the Fushan subtropical forest comprising epiphytes. The epiphytic biomass for the entire forest was estimated to be $3360 \mathrm{~kg} \mathrm{ha}^{-1}$. Data of biomass other than epiphytes are from Lin et al. (1994).

\begin{tabular}{lcc}
\hline Forest component & Biomass $\left(\mathrm{t} \mathrm{ha}^{-1}\right)$ & Epiphyte biomass $(\%)$ \\
\hline Total above-ground & 290 & 1.2 \\
Tree & 271 & 1.2 \\
Above-ground foliage & 7.8 & 43 \\
\hline
\end{tabular}

Average nutrient concentrations of epiphytes varied according to life form and organ (Table 3). Nutrient concentrations of green tissues, including phorophyte foliage, were far higher than those of woody boles and branches of the phorophytes. Concentrations of $\mathrm{N}, \mathrm{P}$ and $\mathrm{Mg}$ in the green tissues of the epiphytes were similar to those of the phorophyte foliage; however, Ca and K concentrations of epiphytic green tissues generally far exceeded those of phorophyte foliage.

The nutrient capital (in $\mathrm{kg} \mathrm{ha}^{-1}$ ) of epiphytes in the entire forest was estimated by multiplying the nutrient concentrations by the epiphytic biomass: $\mathrm{N}=$ 42.4, $\mathrm{P}=1.9, \mathrm{Mg}=5.5, \mathrm{Na}=1.3, \mathrm{Ca}=14.5$ and $\mathrm{K}=28.9$ (Table 4). Although the nutrients contained in the epiphytes comprised less than $5 \%$ of those in the total above-ground biomass (including woody material), the mineral capital contained in epiphytes constituted $21-43 \%$ of that in the above-ground nonwoody foliage. 
Table 2. Composition of epiphytic biomass removed from 18 trees at Fushan in north-eastern Taiwan.

\begin{tabular}{lcc}
\hline Plant material & Biomass $(\mathrm{kg})$ & $\begin{array}{c}\text { Proportion of total } \\
\text { epiphytic biomass (\%) }\end{array}$ \\
\hline Living & & \\
Green & 14.3 & 12.4 \\
$\quad$ Leaves of vascular epiphyte & 59.6 & 51.8 \\
$\quad$ Bryophyte & 73.8 & 64.2 \\
Total green & & \\
$\quad$ Non-green & 3.3 & 2.9 \\
$\quad$ Roots-stems of ferns & 0.8 & 0.7 \\
$\quad$ Roots of flowering plants & 25.2 & 21.9 \\
$\quad$ Stems of flowering plants & 29.3 & 25.5 \\
Total non-green & 103.2 & 89.7 \\
Total living & & \\
Dead & 9.8 & 8.5 \\
Organic substrates of bird's-nest ferns & 2.1 & 1.8 \\
$\quad$ Litter collected by bird's-nest ferns & 11.8 & 10.3 \\
Total dead & 115.0 & 100 \\
Total epiphyte & & \\
\hline
\end{tabular}

\section{DISGUSSION}

In previous studies, the epiphytic biomass for the entire ecosystem was roughly estimated based on data collected for only one to three representative trees (Hofstede et al. 1993, Nadkarni 1984a, b). In contrast, we determined the epiphytic biomass for trees. Furthermore, our sampled trees included every class of dbh; thus, we could examine the relationship between epiphyte loads and the dbh of phorophyte.

The data best fitted a linear regression with $r^{2}=0.87$, and the estimated epiphytic biomass of our sample plot is $403 \mathrm{~kg}$. If the mean epiphytic biomass of each dbh class $(5-10,10-20,20-30,30-40$ and $>40 \mathrm{~cm}$ ) was used separately to estimate epiphytic biomass by multiplying the corresponding biomass for each class with the number of trees in each class, the result was $402.7 \mathrm{~kg}$, which is close to that estimated with the linear regression. It appears that phorophyte dbh is a good predictor of epiphytic biomass in this forest.

A wide range of epiphytic biomass has been reported in temperate and tropical ecosystems in past studies (Table 5). For example, the epiphytic biomass in a Colombian upper montane rain forest (Hofstede et al. 1993) reached a peak of $44 \mathrm{t} \mathrm{ha}^{-1}$, which is almost 10 times that of the Fushan forest. At 3700 $\mathrm{m}$ elevation in the Central Cordillera of Colombia (annual rainfall $1250 \mathrm{~mm}$, temperature $2-6{ }^{\circ} \mathrm{C}$, no dry season), lower evaporative demand and decomposition rates resulting from cool temperatures probably contribute to the greater development of epiphytic biomass of this forest. The relatively old-growth phorophytes in Colombia (424 trees $\mathrm{ha}^{-1}$; $\mathrm{dbh}>45 \mathrm{~cm}$ ) have sufficient time to build up substantial epiphytic biomass. There are fewer large trees (50 trees $\mathrm{ha}^{-1}$, dbh $>45 \mathrm{~cm} ; 1225$ trees $\mathrm{ha}^{-1}$, dbh $>10 \mathrm{~cm}$ ) in the Fushan forest. Additionally, heavier rainfall $\left(3800 \mathrm{~mm} \mathrm{y}^{-1}\right)$ and frequent typhoons probably deplete 


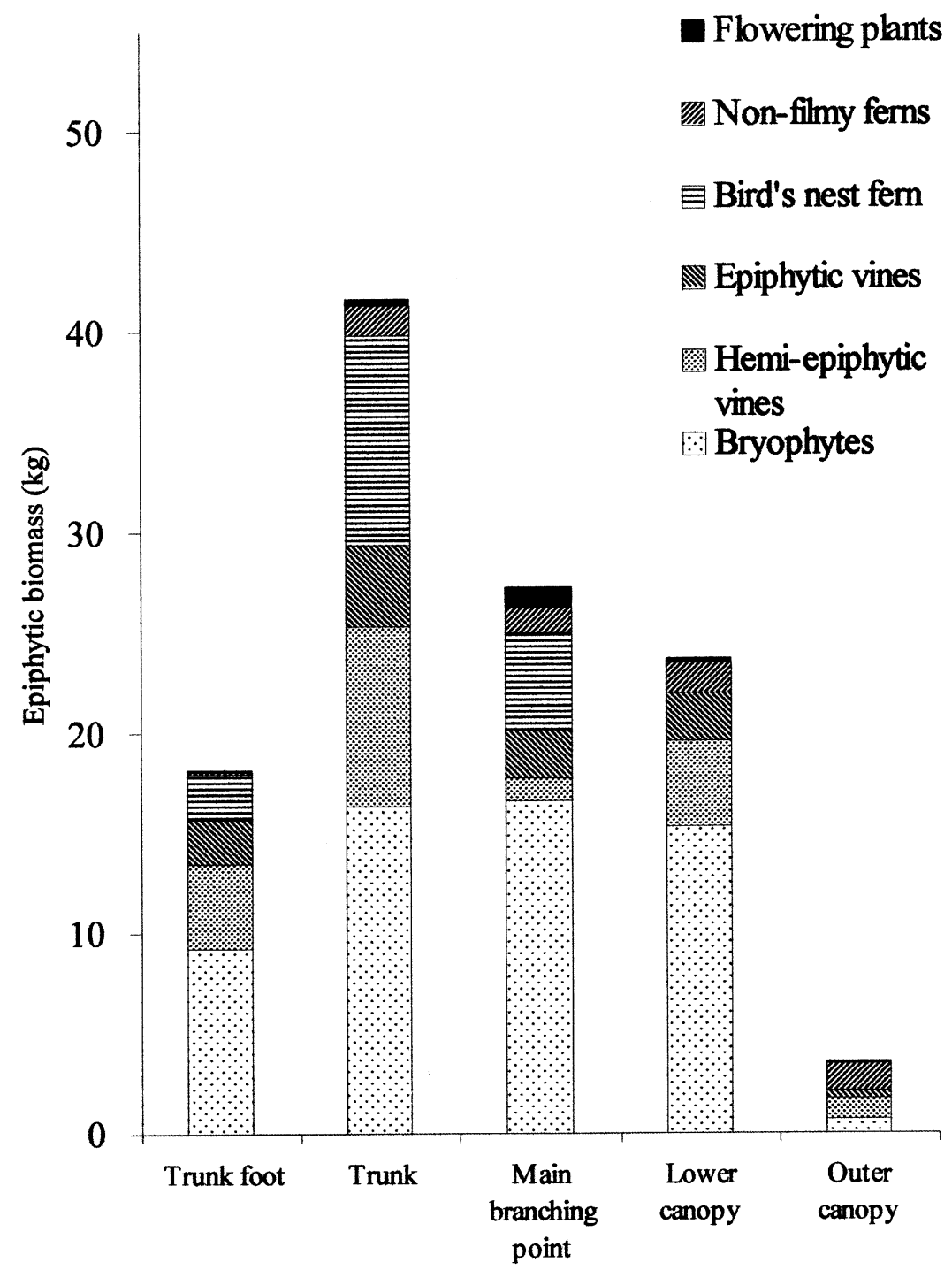

Figure 4. Distribution and composition of epiphytic biomass removed from 18 trees at Fushan in northeastern Taiwan. Total epiphytic biomass is $115 \mathrm{~kg}$.

throughfall nutrient availability and dislodge suspended organic matter of the canopy, which would reduce the accumulation of epiphytic biomass at Fushan.

Nevertheless, the estimate of $3.4 \mathrm{t} \mathrm{ha}^{-1}$ for the epiphytic biomass in the moist subtropical broadleaved evergreen forest of Fushan is within the range of those for tropical rain forests. The most important regional environmental determinant of epiphyte success, however, is less closely linked to the total annual rainfall than to rainfall distribution throughout the year (Gentry \& Dodson 1987). The warm and continuously humid environmental conditions at Fushan are 
Table 3. Nutrient concentrations of epiphytes (mean $\pm \mathrm{SD})\left(\mathrm{mg} \mathrm{g}^{-1}\right) \cdot \mathrm{n}$ is number of epiphyte species, except for bryophytes and suspended soil which are replicated subsamples. Data of phorophytes are from Lin $e t$ al. (1996).

\begin{tabular}{|c|c|c|c|c|c|c|c|}
\hline & Total N & $\mathrm{P}$ & $\mathrm{Mg}$ & $\mathrm{Na}$ & $\mathrm{Ca}$ & $\mathrm{K}$ & $\mathrm{n}$ \\
\hline \multicolumn{8}{|l|}{ Epiphyte } \\
\hline Bryophyte & $18.6 \pm 2.60$ & $1.07 \pm 0.26$ & $1.08 \pm 0.38$ & $0.16 \pm 0.05$ & $5.41 \pm 3.03$ & $20.1 \pm 3.44$ & 21 \\
\hline Woody epiphyte & & & & & & & 2 \\
\hline leaf & $10.9 \pm 3.10$ & $0.66 \pm 0.18$ & $3.95 \pm 3.18$ & $0.50 \pm 0.14$ & $7.74 \pm 0.20$ & $8.52 \pm 6.12$ & \\
\hline root & $6.80 \pm 2.80$ & $0.51 \pm 0.20$ & $3.77 \pm 3.00$ & $0.34 \pm 0.31$ & $4.80 \pm 1.62$ & $16.2 \pm 2.99$ & \\
\hline stem & $6.20 \pm 2.10$ & $0.17 \pm 0.23$ & $0.33 \pm 0.42$ & $0.13 \pm 0.15$ & $1.76 \pm 2.46$ & $1.92 \pm 2.51$ & \\
\hline Hemi-epiphyte vine & & & & & & & 6 \\
\hline leaf & $23.8 \pm 2.20$ & $1.31 \pm 0.49$ & $4.47 \pm 0.99$ & $0.64 \pm 0.30$ & $9.41 \pm 3.37$ & $21.9 \pm 10.9$ & \\
\hline stem & $10.4 \pm 4.10$ & $0.49 \pm 0.28$ & $1.09 \pm 0.52$ & $0.32 \pm 0.27$ & $5.31 \pm 4.08$ & $7.70 \pm 3.31$ & \\
\hline Epiphytic vine & & & & & & & 4 \\
\hline leaf & $8.50 \pm 0.80$ & $1.13 \pm 0.52$ & $9.39 \pm 6.39$ & $1.45 \pm 1.08$ & $16.5 \pm 13.4$ & $30.2 \pm 9.44$ & \\
\hline stem & $16.1 \pm 9.00$ & $0.41 \pm 0.40$ & $1.71 \pm 1.67$ & $0.24 \pm 0.23$ & $5.71 \pm 5.86$ & $7.03 \pm 6.06$ & \\
\hline Bird's nest fern & & & & & & & 3 \\
\hline leaf & $17.2 \pm 5.90$ & $0.68 \pm 0.26$ & $3.83 \pm 1.26$ & $1.03 \pm 0.65$ & $12.9 \pm 7.07$ & $29.8 \pm 12.2$ & \\
\hline fine roots & $18.9 \pm 2.60$ & $0.96 \pm 0.18$ & $1.25 \pm 1.06$ & $0.23 \pm 0.27$ & $3.08 \pm 1.36$ & $1.83 \pm 1.47$ & \\
\hline substrates & $23.1 \pm 3.00$ & $0.23 \pm 0.25$ & $0.44 \pm 0.20$ & $0.08 \pm 0.05$ & $1.45 \pm 0.90$ & $0.68 \pm 0.41$ & \\
\hline litter trapped & $16.7 \pm 2.40$ & $0.82 \pm 0.17$ & $2.10 \pm 0.45$ & $0.23 \pm 0.09$ & $9.69 \pm 2.75$ & $2.63 \pm 0.89$ & \\
\hline root-stem & $16.3 \pm 4.30$ & $0.72 \pm 0.39$ & $2.35 \pm 1.28$ & $0.81 \pm 0.52$ & $5.63 \pm 3.23$ & $9.36 \pm 7.42$ & \\
\hline Filmy fern & $19.7 \pm 3.20$ & $0.80 \pm 0.19$ & $1.25 \pm 0.78$ & $0.16 \pm 0.01$ & $2.38 \pm 0.41$ & $2.63 \pm 2.08$ & 3 \\
\hline Non-filmy fern & & & & & & & 11 \\
\hline leaf & $12.3 \pm 3.90$ & $0.66 \pm 0.56$ & $2.33 \pm 1.93$ & $0.31 \pm 0.25$ & $2.86 \pm 2.43$ & $12.4 \pm 10.5$ & \\
\hline root-stem & $9.00 \pm 1.60$ & $0.40 \pm 0.34$ & $0.97 \pm 0.82$ & $0.13 \pm 0.10$ & $1.90 \pm 1.82$ & $3.30 \pm 2.74$ & \\
\hline Orchid & & & & & & & 4 \\
\hline leaf & 14.8 & 1.10 & 2.92 & 0.32 & 8.98 & 13.0 & \\
\hline stem & 6.90 & 0.53 & 1.86 & 1.18 & 3.05 & 14.1 & \\
\hline Suspended soil & $18.7 \pm 2.30$ & $0.82 \pm 0.09$ & $0.73 \pm 0.33$ & $0.13 \pm<0.01$ & $3.61 \pm 1.23$ & $1.20 \pm 0.30$ & 3 \\
\hline \multicolumn{8}{|l|}{ Phorophyte } \\
\hline Bole & 1.66 & 0.32 & 0.55 & & 1.73 & 1.58 & \\
\hline Small branches & 4.71 & 0.35 & 0.67 & & 2.33 & 3.28 & \\
\hline Leaves & 24.2 & 1.37 & 3.95 & & 5.43 & 12.8 & \\
\hline
\end{tabular}

Table 4. Nutrient capital $\left(\mathrm{kg} \mathrm{ha}^{-1}\right)$ of epiphytes, total above-ground biomass and total above-ground foliage. Proportions of epiphyte nutrient capital are presented in parentheses. Data other than for epiphytes are from Lin et al. (1996).

\begin{tabular}{lccccc}
\hline Forest component & $\mathrm{N}$ & $\mathrm{P}$ & $\mathrm{K}$ & $\mathrm{Ca}$ & $\mathrm{Mg}$ \\
\hline Epiphyte & 42.4 & 1.9 & 28.8 & 14.5 & 5.5 \\
Total above-ground biomass & 951 & 66.6 & 616 & 816 & 196 \\
& $(0.04)$ & $(0.03)$ & $(0.05)$ & $(0.02)$ & $(0.03)$ \\
Total above-ground foliage & 146 & 9.0 & 69.7 & 33.9 & 19.2 \\
& $(0.29)$ & $(0.21)$ & $(0.41)$ & $(0.43)$ & $(0.29)$ \\
\hline
\end{tabular}

most likely responsible for the great diversity and biomass of epiphytes at Fushan.

Comparison of epiphytic biomass to phorophyte foliar biomass reveals a different picture from the comparison to total above-ground biomass. The data for above-ground biomass are from Lin et al. (1994). They set up a 20-m $\times 20-\mathrm{m}$ plot at Fushan. All trees in the plot and all shrubs and herbs in the four 5-m $\times 5$-m subplots were removed and weighed. Unlike the long life of the woody 
Table 5. Biomass of epiphytes in various ecosystems.

\begin{tabular}{|c|c|c|}
\hline Ecosystem/location & $\begin{array}{c}\text { Epiphytic } \\
\text { biomass }\left(\mathrm{t} \mathrm{ha}^{-1}\right)\end{array}$ & Source \\
\hline $\begin{array}{l}\text { Temperate } \\
\text { Moist coniferous forest } \\
\text { Olympic National Park, USA }\end{array}$ & 6.9 & Nadkarni (1984a) \\
\hline $\begin{array}{l}\text { Subtropical } \\
\text { Dry forest } \\
\text { Guanica, Puerto Rico }\end{array}$ & 0.14 & Murphy \& Lugo (1986) \\
\hline $\begin{array}{l}\text { Moist broadleaved forest } \\
\text { Fushan, Taiwan }\end{array}$ & 3.4 & This study \\
\hline $\begin{array}{l}\text { Tropical } \\
\text { Lower montane rain forest }\end{array}$ & 1.4 & Golley et al. (1971) \\
\hline $\begin{array}{l}\text { Upper montane rain forest } \\
\text { New Guinea }\end{array}$ & 5.2 & Edwards \& Grubb (1977) \\
\hline $\begin{array}{l}\text { Submontane forest } \\
\text { Uluguru, Tanzania }\end{array}$ & 2.1 & Pócs (1980) \\
\hline $\begin{array}{l}\text { Elfin cloud forest } \\
\text { Monteverde, Costa Rica }\end{array}$ & 4.7 & Nadkarni (1984b) \\
\hline $\begin{array}{l}\text { Upper montane rain forest } \\
\text { Colombia }\end{array}$ & 44 & Hofstede et al. (1993) \\
\hline
\end{tabular}

components of phorophytes, the epiphytic biomass represents only several years of growth (Matelson et al. 1993). Live epiphytes fall to the forest floor because they are dislodged by wind or animals, or because they have poorly developed root systems or branches break. Other studies have indicated that epiphytes can contribute up to $8 \%$ of the total deposition of biomass and nutrients in fine litter in tropical montane cloud forests (Nadkarni \& Matelson 1992). Fallen epiphytes finally die and decompose, releasing their nutrients.

In this forest, $90 \%$ of the epiphytic biomass consists of living organisms, only $10 \%$ is non-living (Table 2). This distinguishes this forest system from that of the tropical montane rain forest, where humus deposition in the canopy can comprise 26-63\% of the epiphytic biomass (Hofstede et al. 1993, Nadkarni 1984b, Pócs 1980). The thin layer of organic matter found on phorophytes in the Fushan forest may be the result of heavy rainfall and a rapid decomposition rate. In total, green tissue comprises $64 \%$ of the epiphytic biomass, which is close to $15 \%$ of the total above-ground foliage. Thus, the epiphytes greatly increase the primary productivity of this ecosystem.

The vertical distribution of epiphytic biomass can reveal microhabitats at various locations on the phorophytes (Figure 4). Epiphytes that prefer the upper portions of their host tree canopies may have higher light requirements than those in the lower parts of the canopies, or they may be more tolerant of lower humidity, and/or greater degree of drought stress. The ecophysiology of such epiphytes requires further investigation.

Nutrient concentrations of the epiphytes are much higher than those of the woody component of trees, and are similar to those of the tree leaves. Because nutrient sources are limited in the arboreal environment, some epiphytes 
possess specialized absorptive features which make them efficient at intercepting airborne nutrients (Benzing 1990). Epiphytes also increase the surface area of phorophytes for interception of water and nutrients during precipitation events.

The nutrient pools within canopy epiphytes in this study represented 21$43 \%$ of those in the above-ground foliage. In an upper montane rain forest in Colombia (Hofstede et al. 1993), nutrient capital located in the epiphytic load even reached $20-49 \%$ of total above-ground nutrients. Thus, epiphytes can expand both the nutrient storage and absorption capacity of tropical and subtropical forest ecosystems.

\section{AGKNOWLEDGEMENTS}

We would like to thank N. H. Chang and F. J. Mar for technical advice. Help in the field came from Y. C. Wu and Y. C. Lin. Technical help was provided by the staff of the Soil Laboratory of the Silviculture Division of Taiwan Forest Research Institute. We are grateful for financial support from the Pteridophyte Laboratory of the Graduate Institute of Botany of National Taiwan University, and for assistance from the Fushan Experimental Forest.

\section{LITERATURE CITED}

BENZING, D. H. 1990. Vascular epiphytes. Cambridge University Press, Cambridge. 354 pp.

DENISON, W. 1973. Life in tall trees. Scientific American 201:75-80.

EDWARDS, P. \& GRUBB, P. J. 1977. Studies of mineral cycling in a montane rain forest in New Guinea. Journal of Ecology 65:943-969.

GENTRY, A. H. \& DODSON, C. H. 1987. Contribution of non-trees to species richness of a tropical rain forest. Biotropica 19:149-156.

GOLLEY, F., MCGINNIS, K. \& CLEMENTS, R. 1971. La biomass y la estructura de algunos bosques de Darien, Panama. Turrialba 21:189-196.

HOFSTEDE, R. G. M., WOLF, J. H. \& BENZING, D. H. 1993. Epiphyte biomass and nutrient status of a Colombian upper montane rain forest. Selbyana 14:37-45.

JOHANSSON, D. 1974. Ecology of vascular epiphytes in a West African rain forest. Acta Phytogeographica Seucica 59:1-136.

LIN, K.-G., HORNG, F.-W., YU, H.-M. \& MA, F.-C. 1994. Biomass and leaf area index estimates of broadleaf forests in Fushan forest. Bulletin of Taiwan Forestry Research Institute New Series 9:299-315.

LIN, K.-C., HORNG, F.-W., YU, H.-M. \& MA, F.-C. 1996. Estimates of aboveground nutrient accumulation in broadleaf forest of the Fushan forest. Taiwan Journal of Forest Science 11:29-42.

MATELSON, T. J., NADKARNI, N. M. \& LONGINO, J. T. 1993. Longevity of fallen epiphytes in a Neotropical montane forest. Ecology 74:265-269.

MURPHY, P. G. \& LUGO, A. E. 1986. Structure and nutrient capital of a subtropical dry forest in Puerto Rico. Biotropica 18:89-96.

NADKARNI, N. M. 1984a. Biomass and mineral capital of epiphytes in an Acer macrophyllum community of a temperate moist coniferous forest, Olympic Peninsula, Washington state. Canadian Journal of Botany 62:2223-2228.

NADKARNI, N. M. 1984b. Epiphyte biomass and nutrient capital of a neotropical elfin forest. Biotropica $16: 249-256$.

NADKARNI, N. M. \& MATELSON, T. J. 1992. Biomass and nutrient dynamics of epiphytic litterfall in a Neotropical montane forest, Costa Rica. Biotropica 24:24-30.

PAGE, A. L. (ed.) 1982. Methods of soil analysis part 2. (Second edition). Academic Press, New York. 1159 pp. 
PIKE, L. 1978. The importance of epiphytic lichens in mineral cycles. Bryologist 81:247-257.

PÓCS, T. 1976. The role of the epiphytic vegetation in the water balance and humus production of the rain forests of the Uluguru Mountains, East Africa. Boissiera 24:499-503.

PÓCS, T. 1980. The epiphytic biomass and its effect on the water-balance of two rain forest types in the Uluguru mountains. Acta Botanica Academiae Scientiarum Hungaricae 26:143-167. 